\title{
The Effect of Corporate Governance and Ownership Structure on Financial Performance of Listed Companies in Nepal
}

\author{
Surya Bahadur G. C., PhD* \\ Ravindra Prasad Baral**
}

\begin{abstract}
The paper attempts to analyze relationships among corporate governance, ownership structure and firm performance in Nepal. The study comprises of panel data set of 25 firms listed at Nepal Stock Exchange (NEPSE) covering a period of five years from 2012 to 2016. The econometric methodology for the study consists primarily of least squares dummy variable (LSDV) model, fixed and random effects panel data models and two-stage least squares (2SLS) model. The study finds bi-directional relationship between corporate governance and performance. Among corporate governance internal mechanisms; smaller board size, higher proportion of independent directors, reducing ownership concentration, improving standards of transparency and disclosure, and designing appropriate director compensation package are important dimensions that listed firms and regulators in Nepal should focus on. Ownership concentration is found to have positive effect on performance; however, it affects corporate governance negatively. This study raises understanding and provides empirical evidence for endogenous relationship between corporate governance and performance and offers support for principal-principal agency relationship. The results of this study lead to several practical implications for listed firms as well as policymakers of Nepal in promoting sound corporate governance practices and codes. For listed companies, the improvement in compliance with a code of corporate governance or voluntary adoption of best practices can provide a means of achieving improved performance.
\end{abstract}

Keywords: Board structure, corporate governance, ownership structure, principal-principal agency conflict.

\section{INTRODUCTION}

Corporate governance involves a set of relationships between a company's management, its board, its shareholders and other stakeholders. It provides the structure through which the objectives of the company are set and the means of attaining those objectives and monitoring performance are determined (OECD, 2004). There is reasonable consensus among practitioners and academicians about the importance of good corporate governance in the economy (Klapper \& Love, 2004). Good corporate governance contributes to sustainable economic development by enhancing the stability and performance of companies (Mallin, 2008). First, sound corporate governance increases access to external financing for firms, which leads to larger investment, higher growth, and creation of more jobs. Second, it can lower the cost of capital and raise the value of the firm, making investments more attractive,

* Dr. G.C. is Associate Professor in Faculty of Management Studies, Pokhara University

**Mr. Baral is Lecturer in Faculty of Management Studies, Pokhara University

Corresponding author: Dr. Surya Bahadur G.C.Email: suryagc@pu.edu.np 
which in turn can lead to growth and more employment. Additionally, good governance produces better operational performance through better allocation of resources and better management. It reduces the risk of financial crises, which can have devastating economic and social costs. Furthermore, it leads to better relationships with all stakeholders, and thus improve labor relations as well as the climate for improving social aspects such as environmental protection (Bebchuk \& Ferrell, 2009).

In recent years, corporate governance is attaining significance all over the world. Two important factors have led to rapid developments in the area; integration of financial markets and a surge of corporate scandals in developed as well as emerging nations (Srinivasan \& Srinivasan, 2011). As a result, scholarship in the field of corporate governance is growing steadily over the last two decades. Many empirical studies have been conducted over the last two decades to investigate relationship between corporate governance and a firm's performance in the world. Most of the research in the area of corporate governance is done for developed economies, as rich data is only available for these economies where active market for corporate control exists and the ownership concentration is low. Nepal like many developing countries is characterized by relatively weak investor's protection and corporate law enforcement. It is also characterized by the ownership concentration; cross-shareholdings and the dominance of family business (Mohanty, 2004). There are good reasons to postulate that the effectiveness of corporate governance might be quite different in underdeveloped and emerging markets (Saravanan, 2012). Hence, studies on the area of relationship between corporate governance, ownership structure and performance in context of both developing and underdeveloped nations are essential to get better insights in the issue.

One of the major differences in governance systems across countries is in the ownership structure of individual firms (Dharmapala \& Khanna, 2014). As firms in developed economies are widely held, the primary source of agency conflict is between managers and shareholders. It is known as principalagent (PA) conflict (Jensen \& Meckling 1976). However, ownership concentration and low level of investor protection are key features in developing countries. In such scenario, majority shareholders can exploit minority shareholders rights (Saravanan, 2012). Hence, agency conflict in the countries occurs not between principal and agent but between different sets of principals in the firm. This has come to be known as the principal-principal (PP) model of corporate governance, which centers on conflicts between the controlling and minority shareholders in a firm (Young, Peng, Ahlstrom, Bruton, \& Jiang, 2008).

Most of the existing empirical work examining relationship between corporate governance and performance has been undertaken in context of developing economies. Studies in the area for emerging and developing countries are relatively low (Love, 2011). Although some prior studies explore the corporate governance practices in Nepal (World Bank, 2005; Thapa, 2008; Ghimire, 2010, Acharya, 2013; Poudel \& Harvey, 2013), prior studies exploring linkages of corporate governance, ownership structure and performance in the context of small and underdeveloped economy is scanty. In Nepal recent failures of corporate governance practices at some financial institutions has resulted in significant interest of policymakers and regulators for promotion of corporate governance practices. Most of the problems that the Nepalese banking industry has seen so far are related to the corporate governance. All most all of the failures are related to the lack of good governance and ethical standards. Insider lending, related party lending and connectivity, unethical relations etc. have created most of the problems rather than credit risks and the business risks (NRB, 2014).

In the light of the above theoretical underpinnings, the purpose of the study is to empirically 
examine the relationship between corporate governance, ownership structure and performance of the firms in context of an underdeveloped economy. More specifically, the study attempts for consistent estimation of the relationship between corporate governance and performance, by taking into account the inter-relationships among corporate governance, corporate performance, corporate capital structure, and corporate ownership structure. Study in the Nepalese context contributes to emerging literature on corporate governance especially the principal-principal conceptualization.

\section{LITERATURE REVIEW}

Agency theory which offers theoretical foundation for corporate governance is built on the premise that there is an agency relationship wherein the principal delegates the work to the agent and involves risk sharing and conflict of interest between the two. It posits that corporate governance issues arise due to the separation of ownership and management. Berle and Means (1932) conclude that modern corporations are characterized by an inefficient corporate governance structure because ownership is separated from control of the firm. Jensen and Meckling (1976) and Fama and Jensen (1983) also concluded that agency costs occur when the owner and manager are not one. Hence, agency theory is the starting point of most discussions of corporate governance. At the theoretical level, agency theory identifies several reasons why good corporate governance increases firm value and performance (Shleifer \& Vishny, 1997). Corporate managers may have personal goals that conflict with the long-term shareholders' objective of wealth maximization. As a result corporate managers pursue actions that fulfill their own personal interests (Drucker, 1954) at the expense of shareholders. Basically, good governance involves better monitoring, greater transparency, and public disclosure between shareholders and managers. This leads to increased investor trust and a decrease in managers' discretion and expropriation of rents. Well-governed firms are supposed to be less risky and to have more efficient operations and reduced auditing and monitoring costs (Denis, 2001). These elements tend to alleviate the cost of capital and generate higher expected cash flow stream, which, in turn, create higher firm valuation and better performance (Macey, 2008).

There are several research studies that examine the extent to which good governance characteristics positively impact a firm's performance. One of the noteworthy studies is by Stulz (1990) in which the authors argue that good governance should positively impact a firm's market valuation and performance, presumably because better governance gives the firm increased access to capital markets and allows it to obtain capital at more favorable terms. This view is also supported through anecdotal evidence coming from surveys conducted by McKinsey \& Company, which show that investors are more than willing to pay a premium for firms employing better governance practices (Davis, Schoorman, \& Donaldson, 1997). However, other studies (Gompers, Ishii, \& Metrick, 2003) have shown mixed results regarding the direct relationship between a firm's corporate governance practices and its performance. Prior studies identify corporate governance mechanisms like board size, board independence, board committees, ownership structure, and director remuneration to affect firm performance.

The impact of board structure on firm performance is the most studied area of corporate governance (Love, 2011). The board serves as a bridge between owners and managers; its duty is to protect shareholders' interests. Specifically speaking, taking responsibility for managing and supervising, the board should monitor managers' behaviors for shareholders' interests, make important decisions, supervise management team and superintend firms to obey the law. Various empirical studies have established relationship between board structure and composition with corporate governance quality 
and performance. Board composition dimensions like board independence, diversity, diligence, size and committees significantly affect the corporate governance quality (Baker \& Anderson, 2010).

The effectiveness of boards of directors has been shown to depend on the board's size. Early studies by Lipton and Lorsch (1992) and Jensen (1993) propose that large boards are ineffective. They argue that the benefits of a large board are outweighed by the costs of slower decision making, less candid discussions of managerial performance and biases against risk taking. Both of these studies also contend that as the board of directors get bigger, they become less effective because free-riding problems erupt and decisions become harder to make in a timely manner. In contrast Baker and Griffith (2010) find a positive relationship between size of the board and both company performance and effective board monitoring. Researchers have focused on the proportion of executives to independent directors as an indicator of board independence (Davidson, 2005; Peasnell, Pope, \& Young, 2003). Some previous studies have suggested that independent directors are effective monitors because they do not have financial interests in the company or psychological ties to management. They are in a better position to objectively challenge management. Bekiris (2013) have also argued that higher independent director representation on the board provides more vigilant oversight of the monitoring process.

Prior literature identifies board diversity as an important dimension of board composition affecting corporate governance. There are two ways to describe board diversity: the observable diversity (tangible) and non-observable diversity (cognitive). Board directors' age, gender and ethnicity belong to the tangible diversity group and board directors' technical skills, experience, perceptions and education belong to the cognitive category. Demographic dissimilarity in the boardroom seems to affect incentives for replacing the CEOs, the director nomination process, and the design of compensation systems (Macey, 2008). Most of these studies suggest a positive relationship between board gender, racial diversity and firm financial performance (Carter, Simkins, \& Simpson, 2003).

The nature of relation between the ownership structure and corporate governance structure has been the core issue in the corporate governance literature. In most of developing markets the closely held firms (family or promoter controlled) dominate the economic landscape. The main agency problem is not the manager-shareholder conflict (i.e. the agency conflict) but rather the risk of expropriation by the dominant or controlling shareholder at the expense of minority shareholders (Bebchuk \& Ferrell, 2009). The agency problem in these markets is that control is often obtained through complex pyramid structures, interlock directorship, cross shareholdings, voting pacts and/or dual class voting shares that allow the ultimate owner to maintain (voting) control while owning a small fraction of ownership (cash flow rights). The dominant shareholder makes the decisions but does not bear full cost (Mallin, 2008). The negative impact that large family shareholders can have on firm value can be even greater when family members hold executive positions in the firm (Kirkpatrick, 2009; Reinganum, 2009). This has come to be known as the principal-principal (PP) model of corporate governance, which centers on conflicts between the controlling and minority shareholders in a firm (Young, Peng, Ahlstrom, Bruton, \& Jiang, 2008). PP conflicts are characterized by concentrated ownership and control, poor institutional protection of minority shareholders, and indicators of weak governance such as fewer publicly traded firms, lower firm valuations, lower levels of dividends payout, inefficient strategy, less investment in innovation, and, in many cases, expropriation of minority shareholders. Similarly, level of director remuneration, shareholder rights' protection and disclosure and transparency practices are related to corporate governance quality and hence performance (Shleifer \& Vishny, 1997). 
Despite widespread belief in the importance of governance mechanisms for resolving agency problems, the empirical literature investigating the effect of individual corporate governance mechanisms on corporate performance has not been able to consistently identify positive effects (Love, 2011). Nevertheless, the appropriate conclusion to draw from this extensive line of research is not that efforts at improving corporate governance are a waste of time and effort. Rather, there are limitations with a research design that examines the effect on performance of only one dimension of a firm's governance when governance mechanisms are numerous and interaction effects are quite probable (Baker \& Anderson, 2010). Endogeneity is a problem when investigating company-level corporate governance practices and its relationship with performance. According to Hermalin and Weisbach (2008), the interrelationship between corporate governance, ownership structure, capital structure and firm performance are endogenously determined. For instance, firm performance is both a result of the actions of previous directors and a factor that potentially influences the choice of subsequent directors. Also, factors related to unique company characteristics, such as ownership structure and leverage, may affect corporate governance choices and generate spurious correlations with performance. Baker \& Anderson (2010) opine that controlling for all these aspects is difficult when constructing country-level or company-level corporate governance indicators and studying their effects on performance. To conclude, more research in the area is needed to find conclusive empirical evidence.

\section{METHODOLOGY}

\subsection{Nature of the Data}

The study follows post positivist research paradigm using quantitative approach for deducting theorized proposition that sound corporate governance enhance financial performance of firms and is based on secondary data on corporate governance, ownership and financial performance variables collected from published reports of listed firms of Nepal.

\subsection{Sample and Sampling Procedure}

The universe of the study comprises of all the companies listed at Nepal stock exchange (NEPSE). The sampling frame for the study consists of the list of the companies listed at NEPSE as on 30th April 2017. The sampling criteria requirement for selection of the listed firms as the study sample units is the operation period of at least 5 years and publication of annual reports for the five year study period of 2012-2016. Hence, out of 224 listed companies as on 13th March, 2017 stratified purposive sampling technique has been used to select sample units. The stratification variable comprises industry sectors. The NEPSE publishes sub-indices for commercial firms, development firms, finance companies, hotels, hydropower, insurance, manufacturing and processing and others. Among the sectors classified, depository financial institutions and insurance are selected as major sample industry. The rest have been classified in the study as other sectors. These sectors represent the highest number of firms per sector and market capitalization. The sample category for depository financial institutions comprises of commercial banks and development banks only. All the remaining sectors have been categorized as other sectors. The final sample comprises of 25 listed companies and comprise of ten commercial banks, five development banks, five insurance companies and five companies from other sectors like manufacturing, hydropower, hotels etc. The list of the sample units are presented in Appendix II. The basis for selection of sample 
firms is purposive depending on availability of published annual report, ownership structure data and sampling criteria.

\section{3 Data Collection Techniques}

The data has been collected from annual reports and official website of the sample units and reports and databases of regulatory agencies like Nepal Rastra Bank (NRB), Securities Board (SEBON), Insurance Board, and Nepal Stock Exchange (NEPSE). Moreover, cross-validation of data from the different sources has been undertaken to further establish data dependability. A comprehensive corporate governance index has been created using the equally weighted mean scores of corporate governance indicators obtained from the secondary sources.

Corporate governance is a multifaceted concept and difficult to measure. The dominant approach to evaluating the quality of a firm's corporate governance is to construct an index comprising multiple dimensions of a firm's governance mechanisms (Baker \& Anderson, 2010). The governance index computation methodology used in this study is based on the governance indices used in Gompers, Ishii and Metrick (2003), Bebchuk, \& Ferrell (2004), and Brown and Caylor (2004). The governance index used in the study covers four broad areas of corporate governance. The areas are board structure and functioning (7 items), rights of shareholders (5 items), disclosure and transparency (5 items), and compensation (4 items). The corporate governance score used in this is study computed by assigning each of the above 21 items or factors the value of 1 or 0 depending on observance of whether the firm has (or has not) adopted the governance practice. The value of the corporate governance score is obtained by adding all the assigned values (ones and zeros). Higher values indicate good governance quality in the firms and vice versa. In order to determine whether the corporate governance practice is observed or not in the sample listed firms, content analysis of information published on annual reports of the sample units is undertaken.

\subsection{Data Analysis Tools}

The study employs different models to analyze relationship between corporate governance characteristic variables, ownership structure and firm performance. As the study is based on panel data, the OLS estimation will be biased. Hence, the following Least Squares Dummy Variable (LSDV) panel data regression model has been used employing both firm and time dummies for preliminary analysis of relationship among corporate governance mechanisms, ownership structure and firm performance:

$$
\begin{aligned}
\operatorname{PERF}_{\mathrm{it}}= & \alpha_{0}+\beta_{1} \operatorname{INDDIR}_{\mathrm{it}}+\beta_{2} \text { BSIZE }_{\mathrm{it}}+\beta_{3} \mathrm{HHI}_{\mathrm{it}}+\beta_{4} \text { BLINDX }_{\mathrm{it}}+\beta_{5} \mathrm{SHR}_{\mathrm{it}}+\beta_{6} \operatorname{DINDX}_{\mathrm{it}} \\
& \beta_{7} \ln \left(\mathrm{REM}_{\mathrm{it}}\right)+\gamma \overrightarrow{\mathrm{x}}_{\mathrm{it}}+\mathrm{t}_{\mathrm{t}}+\mathrm{d}_{\mathrm{i}}+\varepsilon_{\mathrm{it}}
\end{aligned}
$$

Where $i$ and $t$ represent the firm and periods, respectively, $\mathrm{d}_{\mathrm{i}}$ is the firm-specific effect, $\mathrm{t}_{\mathrm{t}}$ is time effect and $\varepsilon_{\mathrm{it}}$ is the error term. The $\mathrm{X}_{\mathrm{it}}$ variables are vector of control variables. This specification allows for a firm specific fixed effect $d_{i}$, time effects that are common to firms captured by year dummies $\left(t_{t}\right)$, and a random unobserved component $\varepsilon_{\mathrm{it}}$ In the model, $\alpha_{0}=$ intercept, INDDIR= board independence, SIZE = board size, BLINDX = Blau Index as a measure of board diversity, HHI= Herfindahl Hirschman Index as an indicator for ownership concentration, SHR= Shareholders' rights, REM= Executive Remuneration, and. $\beta^{1} \ldots \beta_{7}$ are the beta coefficients of the regression model. The dependent variable PERF is firm performance represented by Tobin's $Q$ and Market to Book value ratio. The control variables used are firm size and age. The Wald, Breusch-Pagan and Hausman tests have been used to determine the proper 
model specification among pooled ordinary least square (OLS), fixed effects, and random effects panel data models.

Brief review of the interrelationships among corporate governance, including capital and ownership structure and corporate performance, suggests that studying the relationship between corporate governance and performance from an econometric viewpoint requires formulating a system of simultaneous equations that specifies the relationships among the aforementioned variables (Love, 2011). As many prior studies have noted, the relationship between corporate governance and company performance is subject to endogeneity, or reverse causality. Specifically, prior empirical evidence reveals possibility of existence of bi-directional relationship between corporate governance and performance. To account for this endogeneity, the study uses a four-equation system to allow for governance, performance, ownership, and capital structure to be potentially endogenous. The study estimates this system of equations using Two-Stage Least Squares (2SLS) estimation utilizing instrumental variables approach. The 2SLS has been undertaken in two stages; first, obtain and estimate the reduced form equations using OLS and save the fitted values for the endogenous variables, and then, estimate the structural equations using OLS, but replace any RHS endogenous variables with their stage one fitted values. The study employs following four-equation system of equations specification based on Bhagat and Bolton (2008).

Performance $=\mathrm{fl}($ Governance, Ownership, Capital Structure, Z1, $\varepsilon 1)$

Governance $=\mathrm{f} 2($ Performance, Ownership, Capital Structure, Z2, $\varepsilon$ 2)

Ownership $=$ f3(Performance, Governance, Capital Structure, Z3, $\varepsilon$ 3)

Capital Structure $=f 4($ Performance, Governance, Ownership, Z4, $\varepsilon$ 4)

Where, the $\mathrm{Zi}$ are vectors of exogenous variables influencing the dependent variables and the $\varepsilon i$ are the error terms associated with exogenous noise and the unobservable features of managerial behavior or ability that explain cross-sectional variation in performance, governance, ownership and capital structure. The $\mathrm{Z} 1$ vector comprises of variables board size and firm size. The Z2 vector comprises of variables board size, firm size and board independence. Similarly, the Z3 vector comprises of variables board size and firm size. Finally, the Z4 vector comprises of variables board size, operating profit margin and firm age. The validity of the instruments used in 2SLS has been examined using the Stock and Yogo (2004) test for weak instruments. Similarly, the Likelihood-ratio (LR) and Hausman (1978) specification test has been used to determine which estimation technique is most appropriate. The Hausman test for endogeneity is used to specifically test for differences between the OLS and 2SLS estimates.

\subsection{Reliability and Validity}

Various measures has been undertaken to ensure reliability and validity of collected data, measurement instruments, and analysis methodology employed. Secondary data has been collected from audited annual reports and database of regulatory agencies which insures credibility of data. Moreover, cross-validation of secondary data from difference sources is made to check consistency of data. The dependent and independent variables used in the study are selected based on their use in prior empirical studies. The panel data regression model and two-stage least squares model specifications are based on diagnostic tests results and prior empirical work. The multiple regression models has been examined for meeting assumptions of multicollinearity, autocorrelation, heteroskedasticity, normality and linearity in order to establish rouboustness of estimations. The corporate governance index formulated has been based incorporating broad dimensions of governance items and the items are based on corporate governance 
guidelines prescribed by Bank of International Settlements (BIS) and International Finance Corporation (IFC) and OECD principles of corporate governance.

\section{RESULTS AND DISCUSSION}

\subsection{Association between Financial Performance and Corporate Governance Variables}

Table 1 below depicts the bi-variate correlation coefficients between key performance indicator variables and corporate governance variables used in the study. The Pearson's correlation is employed and significant correlations are flagged using two-tailed significance test. Only the significant correlation coefficients are displayed on the table. In general, the results reveal that larger board size and higher number of promoter directors have negative influence on performance. Hence, corporate governance best practices should advocate smaller board size and lower promoter representation. Promoter representation on board increases with ownership concentration arising as a result of block shareholding by promoter shareholder group. Higher proportion of independent directors on board, board diversity and better disclosure practice are positively associated with performance measures.

Table 1

Correlation Matrix of Corporate Governance Variables with Key Performance Indicators

\begin{tabular}{|c|c|c|c|c|}
\hline & $\mathrm{ROA}$ & $\mathrm{M} / \mathrm{B}$ & Tobin's Q & Z Index \\
\hline BSIZE & & $-0.223 * *$ & $-0.163 *$ & \\
\hline PRMDIR & $-0.305 * *$ & & $-0.403 * *$ & $-0.413 * *$ \\
\hline INDDIR & $0.293 * *$ & & $0.425 * *$ & $0.413 * *$ \\
\hline BLINDX & $0.228 * *$ & & & $0.341 * *$ \\
\hline DINDX & $0.261 *$ & $0.226 * *$ & $0.441 * *$ & $0.374 * *$ \\
\hline
\end{tabular}

BSIZE $=$ board size, PRMDIR $=$ Proportion of promoter director on board, INDDIR = Proportion of independent directors on board, BLINDX = Blau Index (Measure of board diversity), DINDX = Disclosure index

** and * means the coefficient is significant at $1 \%$ and $5 \%$ level of significance respectively. Only the significant correlations are displayed.

Overall, the results reveal that although all the corporate governance variables are associated with performance measures, they have relatively higher influence on value based measure of performance (Tobin's Q) and firm stability (Z-Index) in comparison to accounting based performance measure (ROA). Domination of promoter director on board, presence of independent directors and disclosure are identified as important corporate governance variables influencing performance. The findings suggests that corporate governance regulation, codes and practices of Nepal should emphasize on reducing board size and promoter ownership concentration, and increasing board independence, diversity and disclosure. Additional insights on the relationship between the corporate governance variables and performance are provided in later sections where output of multiple regression models is discussed.

\subsection{Impact of Corporate Governance Mechanisms on Financial Performance}

This section discusses the results of pooled OLS and panel data models incorporating fixed and random 
effects employed to investigate relationship between corporate governance mechanisms and value based financial performance indicators. If corporate governance practices result in shareholder value creation, the market price per share of the firms is expected to increase. Two value based measure of performance, Tobin's Q and Market to Book Value of Equity ratio are used as dependent variables in the models and the output is presented in Table 2 .

Table 2

Relationship between Performance and Corporate Governance Variables: Output of Panel Data Regression Models

\begin{tabular}{|c|c|c|c|c|c|c|}
\hline & \multicolumn{2}{|c|}{$\begin{array}{l}\text { Model I } \\
\text { (POLS) }\end{array}$} & \multicolumn{2}{|c|}{$\begin{array}{c}\text { Model II } \\
\text { (Fixed effects) }\end{array}$} & \multicolumn{2}{|c|}{$\begin{array}{c}\text { Model III } \\
\text { (Random effects) }\end{array}$} \\
\hline & Tobin $\mathrm{q}$ & MB ratio & Tobin $\mathrm{q}$ & MB ratio & Tobin $\mathrm{q}$ & MB ratio \\
\hline $\mathrm{C}$ & $\begin{array}{l}0.105 \\
0.427\end{array}$ & $\begin{array}{r}-3.960 \\
(7.564)\end{array}$ & $\begin{array}{r}0.158 \\
(0.395)\end{array}$ & $\begin{array}{r}-3.817 \\
(7.345)\end{array}$ & $\begin{array}{l}-0.216 \\
(0.631)\end{array}$ & $\begin{array}{r}-3.435 \\
(10.136)\end{array}$ \\
\hline BSIZE & $\begin{array}{r}-0.024 * \\
0.013\end{array}$ & $\begin{array}{r}-0.268 \\
(0.243)\end{array}$ & $\begin{array}{r}-0.027 * * \\
(0.013)\end{array}$ & $\begin{array}{r}-0.328 \\
(0.240)\end{array}$ & $\begin{array}{r}-0.017 \\
(0.014)\end{array}$ & $\begin{array}{r}-0.250 \\
(0.267)\end{array}$ \\
\hline INDDIR & $\begin{array}{r}0.001 * * \\
0.001\end{array}$ & $\begin{array}{r}-0.009 \\
(0.012)\end{array}$ & $\begin{array}{c}0.001 * * \\
(0.0006)\end{array}$ & $\begin{array}{r}-0.010 \\
(0.012)\end{array}$ & $\begin{array}{r}0.0008 \\
(0.0009)\end{array}$ & $\begin{array}{r}-0.007 \\
(0.016)\end{array}$ \\
\hline BLINDX & $\begin{array}{r}-0.065 \\
0.174\end{array}$ & $\begin{array}{r}0.690 \\
(3.085)\end{array}$ & $\begin{array}{r}-0.025 \\
(0.001)\end{array}$ & $\begin{array}{r}1.023 \\
(3.015)\end{array}$ & $\begin{array}{l}-0.1419 \\
(0.219)\end{array}$ & $\begin{array}{r}-0.658 \\
(3.802)\end{array}$ \\
\hline HHI & $\begin{array}{l}0.043 \\
0.093\end{array}$ & $\begin{array}{r}-5.922 * * * \\
(1.652)\end{array}$ & $\begin{array}{r}0.043 \\
(0.087)\end{array}$ & $\begin{array}{r}-5.843 * * * \\
(1.610)\end{array}$ & $\begin{array}{l}-3.232 * \\
(1.210)\end{array}$ & $\begin{array}{r}-5.779 * * \\
(2.245)\end{array}$ \\
\hline DINDX & $\begin{array}{r}0.001 * \\
0.000\end{array}$ & $\begin{array}{r}0.034^{* *} \\
(0.015)\end{array}$ & $\begin{array}{c}0.001 * * \\
(0.0007)\end{array}$ & $\begin{array}{r}0.033^{* *} \\
(0.014)\end{array}$ & $\begin{array}{r}0.001 \\
(0.001)\end{array}$ & $\begin{array}{r}0.035^{* *} \\
(0.012)\end{array}$ \\
\hline AGMSP & $\begin{array}{r}0.0001 \\
0.003\end{array}$ & $\begin{array}{r}-0.024 \\
(0.056)\end{array}$ & $\begin{array}{l}0.0001 \\
(0.002)\end{array}$ & $\begin{array}{l}-0.027 \\
(0.055)\end{array}$ & $\begin{array}{r}0.004 \\
(0.004)\end{array}$ & $\begin{array}{c}-0.025 \\
(0.070)\end{array}$ \\
\hline Ln(REM) & $\begin{array}{r}0.134 * * * \\
0.043\end{array}$ & $\begin{array}{l}1.323^{*} \\
(0.770)\end{array}$ & $\begin{array}{r}0.132 * * * \\
(0.040)\end{array}$ & $\begin{array}{l}1.292 * \\
(0.752)\end{array}$ & $\begin{array}{r}0.162 * * \\
(0.065)\end{array}$ & $\begin{array}{r}1.309 \\
(1.042)\end{array}$ \\
\hline Age & $\begin{array}{r}0.003 * * * \\
0.001\end{array}$ & $\begin{array}{r}0.122^{* * *} \\
(0.022)\end{array}$ & $\begin{array}{r}0.003 * * * \\
(0.001)\end{array}$ & $\begin{array}{r}0.121 * * * \\
(0.021)\end{array}$ & $\begin{array}{r}0.003 * * \\
(0.001)\end{array}$ & $\begin{array}{r}0.132^{* * *} \\
(0.029)\end{array}$ \\
\hline Size & $\begin{array}{r}-0.001 \\
0.001 \\
\end{array}$ & $\begin{array}{r}-0.063 * * \\
(0.024) \\
\end{array}$ & $\begin{array}{r}-0.001 \\
(0.293) \\
\end{array}$ & $\begin{array}{r}-0.056^{* *} \\
(0.024)\end{array}$ & $\begin{array}{r}-0.0008 \\
(0.001)\end{array}$ & $\begin{array}{r}-0.056^{* *} \\
(0.026) \\
\end{array}$ \\
\hline F-Test (LR) & & & $6.525 * * *$ & $2.538^{* *}$ & & \\
\hline Hausman Test & & & & & $16.437^{*}$ & $21.871 * * *$ \\
\hline R-Squared & 0.415 & 0.402 & 0.506 & 0.401 & 0.208 & 0.268 \\
\hline Adj R-Squared & 0.370 & 0.355 & 0.456 & 0.360 & 0.151 & 0.217 \\
\hline F-Statisctic & $9.179 * * *$ & $8.674 * * *$ & $10.185 * * *$ & $9.608 * * *$ & $3.757 * * *$ & $5.245^{* * *}$ \\
\hline
\end{tabular}

$*, * *, \& * * *$ means the coefficient is significant at $10 \%, 5 \%$ and $1 \%$ level of significance respectively. The values in the parentheses are standard errors.

The output of Model I estimating pooled OLS regression shows that the variables board size, percentage of independent directors, $\mathrm{HHI}$, disclosure and board remuneration have significant relationship with the 
dependent variables. Thus, in corroboration with results of correlation analysis, higher percentage of independent directors on board and smaller board size is found to favorably impact market value. The finding is also consistent with results of prior studies. The results depict that market reacts positively when board independence increases as independent directors are argued to more effectively monitor managerial actions as they have no conflict of interests. Similarly, sound disclosure standards will increase confidence of investors on the market regarding the firms operations. Additionally, the result implies that firms offering attractive compensation package for their board of directors have higher market values. This may be because higher compensation provides incentives to directors to carry out their responsibility diligently which results in effective functioning of the board. However, results show that ownership concentration as measured by HHI affects value negatively. The firm-specific control variable age and size are also significant.

The values of test statistics associated with fixed effects likelihood ratio test rejects the null of hypotheses of no fixed effect or unobserved firm heterogeneity. Moreover, the Hausman test for presence of random effects has also been rejected. The results reveal fixed effects turn out significant and hence fixed effects estimation is suggested. Analogous to the results of pooled OLS, the panel data models II and III reveal that the corporate governance variables board size, board independence, ownership concentration, disclosure practices and director remuneration are important determinants of firm value. However, the results depict that among the explanatory variables; ownership concentration, disclosure and director remuneration are the important variables affecting firm value. Hence, the findings imply that firms seeking to increase value through sound corporate governance should focus on reducing promoter ownership, improving transparency and disclosure and designing compensation package for directors which provides them incentives to align their interest with shareholders long term value maximization. The Model III with correlated random effects is found to have lower robustness as indicated by the relatively lower R-squared values. However, its results are consistent to some extent to the previous two models. Finally, the output of the above three models provide evidence to support the hypothesis that corporate governance practices in the Nepalese firms have positive effect on their market value. Thus, it is found that sound corporate governance maximizes value for shareholders.

\subsection{Relationship among Governance, Ownership, and Performance}

In order to study interrelationship among corporate governance, ownership structure, and performance the study formulates a system of simultaneous equations that specifies the relationships among the abovementioned variables utilizing an instrumental variables approach. Hence, the study employs Two-stage least squares (2SLS) method with corporate governance quality (CGI), performance (ROA), ownership concentration (HHI) and leverage (Liabilities/Equity) as endogenous variables. The control and instrumental variables in the simultaneous equations of 2SLS are board size, operating profit by revenue, independent director, firm size, and age. The 2SLS estimation procedure has been carried out in two steps or stages. First, the reduced form equation is run with only the exogenous variables as explanatory variables for each endogenous variables and fitted values of the endogenous variables computed. Second, the structural equations are estimated replacing only the right hand side endogenous variables with their fitted values obtained from the first step. The output of the 2SLS estimation result is given in following Table 3. 
Table 3

\section{Output of the Two-stage Least Squares (2SLS) Model}

The specifications of the structural equations estimated are given below:

$P E R F_{\text {it }}=\alpha+\beta_{1} O W N_{\text {it }}+\beta_{2} G O V_{\text {it }}+\beta_{3} L E V_{\text {it }}+\beta_{4} L N(T A)_{\text {it }}+\beta_{5} B S I Z E_{\text {it }}+\epsilon_{1}$ $G O V_{\text {it }}=\alpha+\beta_{1} O W N_{\text {it }}+\beta_{2} P E R F_{\text {it }}+\beta_{3} L E V_{\text {it }}+\beta_{4} L N(T A)_{\text {it }}+\beta_{5} B S I Z E_{\text {it }}+\beta_{6} I N D D I R i t+\epsilon_{2}$ $O W N_{\text {it }}=\alpha+\beta_{1} P E R F_{\text {it }}+\beta_{2} G O V_{\mathrm{it}}+\beta_{3} L E V_{\mathrm{it}}+\beta_{4} B S I Z E_{\mathrm{it}}+\beta_{5} L N(T A)_{\mathrm{it}}+\epsilon_{3}$ $L E V_{\mathrm{it}}=\alpha+\beta_{1} O W N_{\mathrm{it}}+\beta_{2} G O V_{\mathrm{it}}+\beta_{3} P E R F_{\mathrm{it}}+\beta_{4} B S I Z E_{\mathrm{it}}+\beta_{5} \mathrm{OPM}_{\mathrm{it}}+\beta_{6} A G E_{\mathrm{it}}+\epsilon_{4}$

\begin{tabular}{|c|c|c|c|c|}
\hline & Performance & Governance & Ownership & Leverage \\
\hline $\mathrm{C}$ & $\begin{array}{r}-2.894 \\
(1.790)\end{array}$ & $\begin{array}{r}-20.938 * \\
(14.324)\end{array}$ & $\begin{array}{r}-29.749 * * \\
(13.529)\end{array}$ & $\begin{array}{r}-0.599 * * \\
(0.239)\end{array}$ \\
\hline Ownership & $\begin{array}{r}0.238 * * * \\
(0.034)\end{array}$ & $\begin{array}{r}-0.650 * * * \\
(0.206)\end{array}$ & & $\begin{array}{r}0.032 * * * \\
(0.006)\end{array}$ \\
\hline Governance & $\begin{array}{r}0.123 * * * \\
(0.013)\end{array}$ & & $\begin{array}{r}-0.588 * * * \\
(0.118)\end{array}$ & $\begin{array}{r}0.008 * * * \\
(0.001)\end{array}$ \\
\hline Leverage & $\begin{array}{r}-0.342 \\
(5.253)\end{array}$ & $\begin{array}{r}2.316^{* * *} \\
(0.459)\end{array}$ & $\begin{array}{c}1.017 * \\
(0.518)\end{array}$ & \\
\hline Performance & & $\begin{array}{r}8.070 * * * \\
(1.223)\end{array}$ & $\begin{array}{r}6.037 * * * \\
(1.553)\end{array}$ & $\begin{array}{r}0.199 * * * \\
(0.064)\end{array}$ \\
\hline $\operatorname{Ln}(\mathrm{TA})$ & $\begin{array}{r}-2.211 * * * \\
(0.758)\end{array}$ & $\begin{array}{r}-13.491 * * \\
(5.552)\end{array}$ & $\begin{array}{r}2.021 \\
(5.063)\end{array}$ & \\
\hline BSIZE & $\begin{array}{r}-0.151 \\
(0.094)\end{array}$ & $\begin{array}{r}3.251 * * * \\
(1.128)\end{array}$ & $\begin{array}{r}0.676 \\
(1.184)\end{array}$ & $\begin{array}{r}-0.091 * * * \\
(0.021)\end{array}$ \\
\hline
\end{tabular}

INDDIR

$0.272 * * *$

(0.059)

OPM

Age

Adj. R-Squared

$*, * *$, and $* * *$ means the coefficient is significant at $10 \%, 5 \%$, and $1 \%$ level of significance respectively. The values in the parentheses are standard errors. Only the significant values are displayed.

Note. The endogenous variables are performance (PERF) measured by ROA, governance (GOV) measured by CG index, ownership concentration (OWN), and capital structure (LEV). The exogenous variables are Board size (BSIZE), natural logarithm of total assets (LN(TA)), firm age (AGE), director independence (INDDIR), and operating profit margin (OPM)).

The result of the 2SLS model shows that ownership structure and governance quality are significant determinants of profitability of the firms in Nepal. Both have positive beta coefficients which indicate that ownership concentration and sound governance practices improve performance. Leverage is found not to have impact on performance. Similarly, governance quality of the firms depends on their ownership 
structure, performance and leverage. Ownership concentration shows negative impact on governance. Linking the finding with effect of ownership on performance, we can state that although ownership concentration has positive effect on performance, it has negative impact on governance quality of firms in Nepal.

Ownership concentration in firms of Nepal mostly takes the form of block holding by promoters. Promoters own controlling stake in most firms. Moreover, promoter holdings in many cases take form of family ownership. Additionally, promoters occupy on average 51.5 percent of boards seats in the firms. Due to their major shareholding promoters have incentives to effectively monitor the board and have ability to do so due to their position as majority shareowners and board seats. This aligns the interest of managers and promoters for enhancing performance of the firms. However, as controlling shareholders are able to extract private benefits of control from the firms, they might engage in such activities through related party transactions or others at the expense of minority shareholders (Bhagat \& Bolton, 2008). In environment of stringent corporate governance system such rent seeking behavior or expropriation is difficult (Love, 2011). Hence, promoter may have little or no incentive to improvise governance quality in the firms. The findings offer empirical evidence for presence of principal-principal agency conflict in Nepal.

Overall, the results reveal that performance is seen to enhance governance practices as revealed by its significant and positive beta coefficient. Firms with superior performance are found more likely to adopt best corporate governance practices. Associating the finding with previous results of positive association of governance with performance, it can be stated that two-way or bi-directional relationship exists between performance and governance supporting findings of Bhagat and Bolton (2008) in context of closely held bank dominated economy like Nepal. This reverse causality provides support for endogeneity between governance and performance of Nepalese firms. Thus, enhancement in governance quality improves financial performance of the firms which further results in better governance practices. In other words, well governed firms are found to perform well and vice-versa.

The study empirically investigates the relationship between corporate governance and firm performance in context of Nepal which is characterized by less developed capital market, low level of investor protection, dominance of family held firms, and ownership concentration in form of promoter and family shareholding. In corroboration to previous studies (Gompers, Ishii, \& Metrick, 2003; Klapper \& Love, 2004; Bhagat \& Bolton, 2008; Vo \& Phan, 2013; GC, 2016), the study finds bi-directional and positive relationship between corporate governance and firm performance. Additionally, smaller board size is found to effect performance positively. The findings are consistent with Lipton and Lorsch (1992) and Jensen (1993) who propose that large boards are ineffective. The benefits of a large board are outweighed by the costs of slower decision making, less candid discussions of managerial performance, and biases against risk taking. Small boards are more effective than large boards because they have a high degree of membership coordination, less communication difficulties, and a lower incidence of severe free-rider problems.

Board independence is found to be an important factor affecting performance. The findings are consistent with Bekiris (2013), Davidson (2005) and Peasnell, Pope, and Young, 2003 who find that that higher independent director representation on the board provides more vigilant oversight of the monitoring process. Independent directors are effective monitors because they do not have financial interests in the company or psychological ties to management. In support to the principal-principal perspective of corporate governance, the study finds that ownership concentration resulting from higher promoter 
shareholding negatively impacts corporate governance. Consistent to Anderson and Reeb (2003), the results indicate that ownership concentration might result in controlling shareholder expropriation of private benefits of control which reduces firm performance and value. Although ownership concentration is found have negative impact on governance it is found to impact performance positively supporting "Managerial-disciplining hypothesis" which predicts positive relationship between block shareholding and corporate governance as block shareholders play a crucial role in firm performance because they have more skills, time, and interest to supervise and monitor effectively (Shleifer \& Vishny, 1986).

\section{CONCLUSION}

The study offers empirical evidence for relationship among corporate governance, ownership structure and performance of firms in the context of economy characterized by less developed capital market, prevalence of family-owned and closely held firms, and less investor protection. As conjectured by the agency theory, the study finds that well governed firms are more likely to achieve better financial performance. Corporate governance is found to have more effect on market value as compared to accounting measures of performance. It means well governed firms are valued more in the market. Among corporate governance internal mechanisms; smaller board size, higher proportion of independent directors, reducing ownership concentration, improving standards of transparency and disclosure, and designing appropriate director compensation package are important dimensions that listed firms and regulators in Nepal should focus on. Additionally, bi-directional relationship is found between corporate governance and firm performance.

Ownership structure of the listed firms is identified as a key mechanism that determines the standards of corporate governance practices and hence their stability and performance. Ownership concentration has supplementary effect in monitoring managerial actions for promoting financial performance. However, in contrast to the effect of ownership concentration on performance, its impact on governance is negative. Hence, ownership concentration especially in form of local promoters controlling stake provides them incentives and power to promote their self-interest at expense of minority shareholders resulting in principal-principal conflict of interests which declines market value of the listed firms. The study raises understanding and provides empirical evidence for endogenous relationship between corporate governance and performance and support for principal-principal agency relationship. Hence, this study extends the current literature on corporate governance theories relating to the underdeveloped and small economy. The conclusions of this study lead to several practical implications for listed firms as well as policymakers of Nepal in further development of the corporate governance codes that consider country-specific characteristics rather than inheriting and adopting a bundle of corporate governance mechanisms from other developed countries. For listed companies, the improvement in compliance with a code of corporate governance or voluntary adoption of best practices can provide a means of achieving improved performance.

One limitation of this study is the development of a corporate governance index. The binary coding with equal weighting used to construct the CGI may not reflect the relative importance of the different corporate governance provisions. Future research may assign weights to each of the corporate governance provisions but this may have the disadvantage of making subjective judgments relative to the importance of each corporate governance provision. Furthermore, the study includes only internal corporate governance mechanisms limiting the scope of the study. As the study reveals that ownership 
structure is important variable for corporate governance, detailed study focusing on impact of ownership structure on performance is required. Additionally, the impact of ownership concentration on accounting measures is positive while the effect on market value is negative. This issue requires further investigation as it indicates dividend policy, or sub-optimal use of retained profits causing interaction effect of ownership and governance on performance. Most of the listed firms in Nepal are family-owned; hence, it is important to study impact of family ownership on performance. Finally, the study focused only on internal corporate governance mechanisms; hence, a study of effect of external governance mechanism on performance provides a rich vein for future research.

Acknowledgements: The paper and the research behind it would not have been possible without the support by faculty research grants offered by Pokhara University Research Center (PURC).The authors express their gratitude to the PURC for the support.

\section{REFERENCES}

Acharya, R. (2013). Corporate governance and firm performance in Nepal. Reshaping Organizations to Develop Responsible Global Leadership, Conference Proceedings, 21-47.

Aglietta, M. (2008). Corporate governance and the long-run investor. International Review of Applied Economics, $22(4), 407-427$.

Alegria, C., \& Schaeck, K. (2008). On measuring concentration in banking systems. Finance Research Letters, 5(1), 59-67.

Baker, T., \& Anderson, S. J. (2010). Predicting corporate governance risk: Evidence from the Directors' and Officers' liability insurance market. Chicago Law Review, 74, 462-487.

Bebchuk, L., \& Ferrell, A. (2009). What matters in corporate governance? Review of Financial Studies, 22(2), $783-827$.

Bekiris, F. V. (2013). Ownership structure and board structure: Are corporate governance mechanisms interrelated? Corporate Governance: The International Journal of Business in Society, 13(4), 352-364.

Berle, A., \& Means, G. (1932). The modern corporation and private property. New York: Macmillan.

Bhagat, S., \& Bolton, B. (2008). Corporate governance and firm performance. Journal of Corporate Finance, 14(3), 257-273.

Braun, M., \& Levy-Yeyati, E. (2002). The role of banks in the transmission of shocks: Micro evidence from Argentina 1996-1999. Universidad Torcuato Di Tella.

Carter, D. A., Simkins, B. J., \& Simpson, W. G. (2003). Corporate governance, board diversity, and firm value. Financial Review, 38(1), 33-53.

Davis, J. H., Schoorman, F. D., \& Donaldson, L. (1997). Toward a Stewardship Theory of Management. The Academy of Management Review, 22(1), 20-47.

Denis, D. J., \& Kruse, T. A. (2001). Managerial discipline and corporate restructuring following performance decline. Journal of Financial Economics, 55, 391-424.

Dharmapala, D., \& Khanna, V. (2013). Corporate governance, enforcement, and firm value: Evidence from India. Journal of Law, Economics and Organization, 29(5), 1056-1084.

Fama, E. F., \& Jensen, M. C. (1983). Separation of ownership and control. Journal of Law and Economics, 26, 301-324.

G. C., S. B. (2016). Corporate governance and firm performance: Empirical evidence from India. Journal of 
Business and Management Research, 1, 48-66.

Ghimire, S. (2010). Is corporate governance priced at stock market? An evidence from Nepalese listed firms. Paper presented at International Seminar on Management, Nepal.

Gompers, P. A., Ishii, J. L., \& Metrick, A. (2003). Corporate governance and equity prices. Quarterly Journal of Economics, 118(1), 107-155.

IMF (2014). Financial sector reform in Nepal. International Monetary Fund Working Paper.

Jensen, M. C. (1993). The modern industrial revolution, exit, and the failure of internal control systems. Journal of Finance, 48, 831-880.

Jensen, M. C., \& Meckling, W. (1976). Theory of the firm: Managerial behavior, agency cost and ownership structure. Journal of Financial Economics, 3, 305-360.

Klapper, L. F., \& Love, I. (2004). Corporate governance, investor protection, and performance in emerging markets. Journal of Corporate Finance, 10(5), 703-728.

Lipton, M., \& Lorsch, J. W. (1992). A modest proposal for improved corporate governance. The Business Lawyer, 59-77.

Love, I. (2011). Corporate governance and performance around the world: What we know and what we don't. The World Bank Research Observer, 26(1), 42-70.

Mallin, C. (2008). Institutional shareholders: Their role in the shaping of corporate governance. International Journal of Corporate Governance, 1(1), 97-105.

Mohanty, P. (2004). Institutional investors and corporate governance in India. Retrieved from http://ssrn.com/ abstract $=353820$.

OECD (2004). OECD Principles of corporate governance. Retrieved from http://www.oecd.org/ dataoecd/32/18/31557724.pdf

Peasnell, K.V., Pope, P.F., \& Young, S. (2001). Managerial equity ownership and the demand for outside directors. Working paper, Lancaster University.

Poudel, R. P. S., \& Hovey, M. (2013). Corporate governance and efficiency in Nepalese commercial firms. International Review of Business Research Papers, 9(4), 53-64.

Saravanan, P. (2012). Corporate governance and company performance: A study with reference to manufacturing firms in India. Journal of Political Economy, 12(1), 155-175.

Shleifer, A., \& Vishny, R. (1986). Large shareholders and corporate control. Journal of Political Economy, 95, $461-488$.

Srinivasan, P., \& Srinivasan, V. (2011). Status of corporate governance research in India: An exploratory study. Journal of Business Ethics, 10, 50-75.

Stulz, R. M. (1990). Managerial discretion and optimal financing policies. Journal of Financial Economics, (26), 3-27.

Thapa, R. B. (2008). Corporate governance: Need and significance in Nepalese firming system. Paper presented at international conference 'Challenges of Governance in South Asia,' Kathmandu. Dec 15- 16.

World Bank (2005). Report on the Observance of Standards and Codes (ROSC), Corporate Governance Country Assessment: Nepal.

Young, M. N., Peng, M. W., Ahlstrom, D., Bruton, G. D., \& Jiang, Y. (2008). Corporate governance in emerging economies: A review of the Principal-Principal perspective. Journal of Management Studies, 45(1), 196220. 
Appendix I

Operationalization of Variables

\begin{tabular}{lll}
\hline \multicolumn{1}{c}{ Variable } & \multicolumn{1}{c}{ Measure } & \multicolumn{1}{c}{ Operational definition } \\
\hline $\begin{array}{l}\text { Dependent variables } \\
\text { Market to book value } \\
\text { ratio }\end{array}$ & M/B ratio & $\begin{array}{l}\text { The ratio of market capitalization of equity to book value } \\
\text { of equity. }\end{array}$ \\
\hline Tobin's Q & Tobin' Q & $\begin{array}{l}\text { The ratio of market value to replacement value of total } \\
\text { assets measured as the market value of equity plus the book } \\
\text { value of debt divided by the book value of total assets. }\end{array}$
\end{tabular}

Independent variables

\begin{tabular}{lll}
\hline Board independence & INDDIR & Percentage of independent directors on the board. \\
\hline Board size & BSIZE & Total number of board of directors. \\
\hline Board diversity & $\begin{array}{l}\text { Blau Index } \\
\text { (BLINDX) }\end{array}$ & $\begin{array}{l}\text { Board diversity measure in terms of academic background } \\
\text { of board of directors. }\end{array}$
\end{tabular}

BlauIndex $=1-\sum_{k=1}^{K} P_{k}^{2}$

Where, $\mathrm{k}=$ attribute level (in this study academic background) and $\mathrm{k}=1,2, \ldots \mathrm{K} . \mathrm{Pk}=$ the proportion of directors who show attribute $\mathrm{k}$. The value of the index lies between 0 to maximum value given by $(\mathrm{K}-1) / \mathrm{K}$. Higher value of the index denotes higher board diversity and viceversa.

Ownership concentration
HerfindahlHirschman Index (HHI)
It is the sum of the squares of proportionate ownership of shareholders. Mathematically:

$H H I_{t}=\sum_{i=1}^{N} S_{i t}^{2}$

Where, Sit is the proportion of stock ownership of shareholder $\mathrm{i}$ in year $\mathrm{t}$ and $\mathrm{N}$ is the total number of shareholders (Mathematically; Sit $=$ Number of shares owned by shareholder i /Total number of outstanding shares). Contrary to the n-Shareholder concentration ratios, in the calculation of $\mathrm{HHI}$, all shareholders are taken into account. HHI stresses the importance of larger block holders by giving them a higher weight than smaller shareholders. Larger value of HHI indicates higher ownership concentration and vice-versa (Alegria \& Schaeck, 2006).

\begin{tabular}{lll}
\hline Board compensation & Ln( REM $)$ & Natural logarithm of total annual board remuneration \\
\hline Shareholder rights & AGMSP & Percentage of shareholder participation at the AGM \\
\hline
\end{tabular}


Appendix I (Continue)

\begin{tabular}{|c|c|c|}
\hline \multicolumn{3}{|l|}{ Endogenous variables } \\
\hline Return on assets & ROA & Ratio of net income to total assets. \\
\hline Leverage & LEV & $\begin{array}{l}\text { Leverageiscapitalstructuremeasurecalculatedasthedebt-to- } \\
\text { total assetsratio. }\end{array}$ \\
\hline Ownership structure & OWN & $\begin{array}{l}\text { Cumulative percentage of equity shareholding by ten largest } \\
\text { shareholders used as measure of ownership concentration. }\end{array}$ \\
\hline $\begin{array}{l}\text { Corporate } \\
\text { governance }\end{array}$ & CGINDEX & $\begin{array}{l}\text { Corporate governance index computed from equally } \\
\text { weighted } 21 \text { items related to } \mathrm{CG} \text { best practices. }\end{array}$ \\
\hline \multicolumn{3}{|l|}{ Instrument variables } \\
\hline Age & AGE & Years of operation \\
\hline Firm size & LN (TA) & Natural logarithm of totalassetsofthefirm. \\
\hline $\begin{array}{l}\text { Operating } \\
\text { margin }\end{array}$ & OPM & Ratio of operating profit to total revenue. \\
\hline
\end{tabular}

Others

Firm stability Z-Index

Firm stability measure based on profitability, capitalization and business risk. Mathematically:

$$
Z-\text { Index }_{i t}=\frac{R O A_{i t}+E_{i t} / T A_{i t}}{\sigma\left(R O A_{i t}\right)}
$$

Where, ROA is the return on assets calculated by the ratio of pre-tax profits to total assets, E/TA is the equity to total assets ratio and $\sigma(\mathrm{ROA})$ is the standard deviation of return on assets. In calculation of the standard deviation of ROA, we follow Levy-Yeyati and Micco (2007) and calculate it by using three year moving standard deviation method. Finally, i represent ithfirm and $t$ is fiscal year $t$.

Appendix II

\begin{tabular}{|c|c|c|c|c|c|}
\hline \multirow{2}{*}{ S. N. } & Company name & \multirow{2}{*}{ No. of $\mathrm{SH}^{\mathrm{a}}$} & \multirow{2}{*}{ Paid up value } & \multirow{2}{*}{ Net profit } & \multirow{2}{*}{ NWPS } \\
\hline & COMMERCIAL BANKS & & & & \\
\hline 1 & Bank of Kathamandu Ltd. & 55575 & 5629576.00 & 655275.70 & 160.38 \\
\hline 2 & Citizens Bank International Ltd. & 80866 & 8029160.01 & 1080377.50 & 100.00 \\
\hline 3 & Everest Bank Ltd. & 46957 & 6035235.92 & 1730207.03 & 253.28 \\
\hline 4 & Himalayan Bank Ltd. & 13562 & 6491623.50 & 1935907.63 & 180.31 \\
\hline 5 & Laxmi Bank Ltd. & 46988 & 8221666.95 & 677127.18 & 128.35 \\
\hline 6 & Macchhapuchre Bank Ltd. & 31213 & 6598700.00 & 898222.68 & 124.43 \\
\hline 7 & Nabil Bank Ltd. & 26241 & 8043221.00 & 2819333.75 & 228.00 \\
\hline 8 & NMB Bank Ltd. & 86514 & 6461774.33 & 115065.00 & 166.07 \\
\hline
\end{tabular}

Sample Listed Firms 


\section{Appendix II (Continue)}

\begin{tabular}{llllll}
\hline 9 & Siddhartha Bank Ltd. & 57081 & 6826117.16 & 1254918.00 & 130.28 \\
10 & Standard Chartered Bank Ltd. & 134726 & 4005715.33 & 1292494.63 & 296.18 \\
\hline DEVELOPMENT BANKS & & & & \\
\hline 11 & Gandaki Bikas Bank Ltd. & 29311 & 1843926.20 & 298954.96 & 150.49 \\
12 & Kamana Sewa Bikas Bank Ltd. & 36862 & 2062769.85 & 105022.00 & 100.00 \\
13 & Shangrila Development Bank Ltd. & 15745 & 17623.84 & 215446.38 & 142.39 \\
14 & Tinau Development Bank Ltd. & 13975 & 460849.90 & 80160.39 & 126.36 \\
15 & Garima Bikash Bank Ltd. & 47124 & 2204243.48 & 222017.42 & 128.31 \\
\hline INSURANCE COMPANIES & & & & \\
\hline 16 & Asian Life Insurance Co. Ltd. & 16499 & 805593.24 & 99166.26 & 122.79 \\
17 & Guras Life Insurance Co. Ltd. & 28099 & 594000.00 & 41819.17 & 125.63 \\
18 & NLG Insurance Company Ltd. & 16870 & 512325.00 & 229513.81 & 249.00 \\
19 & Nepal Life Insurance Co. Ltd. & 154043 & 3096428.63 & 906634.25 & 259.81 \\
20 & Prime Life Insurance Co. Ltd. & 27799 & 610200.00 & 145884.00 & 247.68 \\
\hline OTHERS & & & & \\
\hline 21 & Arun Valley Hydropower Co. Ltd. & 23240 & 933012.30 & 64488.86 & 113.88 \\
22 & Ridi Hydropower Dev. Co. Ltd. & 63979 & 472595.30 & 18159.56 & 107.70 \\
23 & Nepal Grameen Bikas Bank Ltd. & 127793 & 655000.00 & 245805.32 & 125.16 \\
24 & Oriental Hotel Ltd. & 29843 & 791725.75 & 108128.92 & 228.90 \\
25 & Nepal Doorsanchar Company Ltd. & 13296 & 150000.00 & 13554439.44 & 608.87 \\
\hline
\end{tabular}

${ }^{a} \mathrm{SH}=$ Shareholders, ${ }^{b}$ NWPS $=$ Net Worth Per Share

Source: Annual Report, NEPSE (Amounts in '000) 